ISSN 0854-9818

Jan. 2000

\title{
Dampak Pembangunan Sektoral terhadap Konversi dan Degradasi Hutan Alam: Kasus Pembangunan HTI dan Perkebunan di Indonesia
}

Hariadi Kartodihardjo dan Agus Supriono

CENTER FOR INTERNATIONAL FORESTRY RESEARCH

Office address: Jalan CIFOR, Situ Gede, Sindang Barang, Bogor 16680, Indonesia

Mailing address: P.O. Box 6596 JKPWB, Jakarta 10065, Indonesia

Tel.: +62 (251) 622622; Fax: +62 (251) 622100

E-mail: cifor@cgiar.org

Website: http://www.cgiar.org/cifor 


\section{Sistem CGIAR}

Consultative Group on International Agricultural Research (CGIAR) merupakan kelompok donor informal dari 41 donor dunia baik sektor swasta maupun masyarakat yang dibentuk guna mendukung jaringan kerja 16 lembaga penelitian pertanian internasional. Sistem CGIAR didirikan pada tahun 1971, di mana CIFOR merupakan anggota terbaru, adalah bagian dari sistem penelitian pertanian global yang menerapkan solusi ilmiah bagi permasalahan yang dihadapi oleh masyarakat yang tidak mampu di seluruh dunia.

\section{CIFOR}

CIFOR dibentuk di bawah Sistem CGIAR sebagai tanggapan terhadap keprihatinan dunia akan konsekuensi sosial, lingkungan dan ekonomi yang disebabkan oleh kerusakan dan kepunahan hutan. Kegiatan penelitian dilakukan melalui kerjasama kemitraan dengan perorangan dan lembaga penelitian di negara-negara berkembang dan maju. Sifat dan lamanya kerjasama ini ditentukan oleh kajian masalah yang sedang dihadapi. Agenda penelitian ini selalu dikaji ulang dan dapat berubah sewaktu-waktu jika mitra kerja CIFOR menemukan masalah dan kesempatan baru. 


\section{Daftar Isi}

\begin{tabular}{|c|c|}
\hline Ringkasan & \\
\hline Pendahuluan & 1 \\
\hline Pembangunan HTI dan Perkebunan & \\
\hline Hutan Tanaman Industri & \\
\hline Perkebunan & \\
\hline Konversi Hutan Alam & \\
\hline Kerusakan Hutan Alam oleh HPH & \\
\hline Alokasi Hutan Konversi & \\
\hline Perambahan Hutan Konservasi dan Hutan Lindung & \\
\hline Analisis Kebijakan Pembangunan HTI & \\
\hline dan Perkebunan & \\
\hline $\begin{array}{l}\text { Reaksi Pengusaha: Orientasi pada kayu hasil } \\
\text { pembukaan hutan alam }\end{array}$ & \\
\hline Sengketa Agraria dan Dampak Sosial & \\
\hline Kontroversi Kebijakan HTI & \\
\hline Kebijakan Tata Guna Hutan & 10 \\
\hline Perubahan Kebijakan di Era Refomasi & 10 \\
\hline Ringkasan Penemuan dan Rekomendasi & I \\
\hline Ringkasan Penemuan & 11 \\
\hline Rekomendasi & 12 \\
\hline Ucapan Terimakasih & \\
\hline Catatan Akhir & 12 \\
\hline Daftar Pustaka & \\
\hline
\end{tabular}




\title{
Dampak Pembangunan Sektoral terhadap Konversi dan Degradasi Hutan Alam: Kasus Pembangunan HTI dan Perkebunan di Indonesia
}

\author{
Hariadi Kartodihardjo* dan Agus Supriono**
}

\begin{abstract}
Ringkasan
Paper ini mengkaji pelaksanaan konversi hutan alam di Indonesia yang digunakan untuk pembangunan hutan tanaman industri (HTI) dan perkebunan, khususnya kelapa sawit dan karet. Tujuannya adalah untuk mengetahui dampaknya, baik terhadap kerusakan hutan alam maupun masyarakat yang tinggal di dalam dan di sekitarnya, dan juga untuk mengetahui apakah kebijakan di masa lalu dan yang berjalan saat ini mampu menyelesaikan permasalahanpermasalahan yang ditimbulkannya.
\end{abstract}

Beberapa penemuan dari studi ini adalah: (1) kebijakan pembangunan HTI melegitimasi dan mendorong kerusakan hutan alam; (2) subsidi bagi pembangunan HTI sebenarnya tidak diperlukan; (3) pembangunan perkebunan telah mengkonversi lebih banyak lahan daripada yang dibutuhkan untuk mendapatkan tambahan keuntungan dari kayu hasil pembukaan lahan; (4) sistem klasifikasi penggunaan lahan hutan yang tumpang tindih dan tidak kunjung dapat diselesaikan telah menjadi sumber keuntungan bagi para pengembang melalui lepasnya hak-hak masyarakat dan semakin memburuknya kehidupan mereka yang tinggal di dalam dan di sekitar hutan; dan (5) pemecahan masalah ini dihambat oleh kaku dan kuatnya pendekatan top-down serta tidak adanya pengakuan bagi hak-hak masyarakat adat terhadap lahan hutan.

Direkomendasikan bahwa hutan alam yang masih tersisa di dalam kawasan hutan konversi segera dialihfungsikan sebagai hutan tetap, sehingga pembangunan HTI dan perkebunan dilakukan benar-benar dalam lahan tidak berhutan, serta memberikan kewenangan redistribusi lahan hutan kepada organisasi pengelola hutan di daerah.

\section{Pendahuluan}

Perkembangan pembangunan HTI dan perkebunan secara besar-besaran mempunyai latar belakang yang berbeda. Pembangunan HTI lebih dilatarbelakangi oleh timbulnya hutan produksi yang tidak produktif dalam jumlah yang luas dan insentif yang menarik swasta. Sedangkan pembangunan perkebunan, terutama kelapa sawit, lebih dirangsang oleh tingginya permintaan pasar ekspor. Kebijakan pemerintah yang menyangkut konversi hutan dan peruntukan lahan serta berbagai paket kemudahan investasi mendorong pertumbuhan pembangunan sektor ini.

Sejak akhir tahun 1970-an, Indonesia mengandalkan hutan alam sebagai penopang pembangunan ekonomi nasional, dan Hak Pengusahaan Hutan (HPH) menjadi sistem yang dominan dalam memanfaatkan hasil hutan dari hutan alam. Tata Guna Hutan Kesepakatan (TGHK) dan Rencana Tata Ruang Wilayah Propinsi (RTRWP) ${ }^{1}$ digunakan untuk merancang dan mengendalikan pembangunan HPH, HTI dan perkebunan, terutama perkebunan besar, agar dapat meminimumkan dampak negatif terhadap lingkungan dengan cara sesedikit mungkin mengkonversi hutan alam.
Dalam pelaksanaannya, HPH telah mendahului sebagai penyebab degradasi hutan alam. Degradasi ini semakin besar ketika pada tahun 1990 pemerintah mengundang swasta untuk melakukan pembangunan HTI melalui sejumlah insentif. Demikian pula tingginya laju penanaman kelapa sawit yang dilakukan dengan mengkonversi hutan. Padu serasi antara TGHK dan RTRWP yang dilakukan secara top-down belum dapat menyelesaikan masalah, bahkan menghadirkan dampak negatif terhadap kehidupan sosial ekonomi masyarakat.

Pembangunan HTI dan perkebunan dapat berkembang mengingat - berdasarkan TGHK dan RTRWP - lahan masih tersedia. Pemerintah mengatur penggunaan lahan untuk pembangunan HTI yaitu pada kawasan hutan produksi berdasarkan TGHK dan yang kondisinya tidak produktif. Sedangkan untuk pembangunan perkebunan, pemerintah mengalokasikan lahan di luar kawasan hutan berdasarkan klasifikasi TGHK atau dalam lahan budidaya nonkehutanan berdasarkan klasifikasi RTRWP.

\footnotetext{
*Staf Pengajar pada Fakultas Kehutanan Institut Pertanian Bogor. E-mail: hariadi@indo.net.id

**Staf Peneliti pada Asosiasi Penelitian Perkebunan Indonesia, Bogor.
} 
Dalam pelaksanaannya, padu serasi antara TGHK dan RTRWP tidak dapat digunakan sebagai pegangan yang pasti. Hal ini disebabkan pertama, secara de facto, pendekatan padu serasi tidak memecahkan masalah adanya hak-hak masyarakat lokal akan lahan. Kedua, banyak intervensi penggunaan lahan dari pusat. Oleh karena itu, dalam pelaksanaan pembangunan perkebunan dan HTI masalah penggunaan lahan tidak dapat dihindari.

Sampai sejauh mana masalah-masalah institusi dan ekonomi politik berpengaruh terhadap penetapan kebijakan dan implementasi pembangunan HTI dan perkebunan merupakan bagian pengamatan terpenting dari paper ini. Data dan informasi yang digunakan untuk menyusun paper ini berasal dari sumber-sumber resmi pemerintah, media masa, pustaka, wawancara, serta pengalaman penulis sendiri.

Paper ini terdiri atas empat bagian. Bagian pertama memberikan informasi tentang perkembangan pembangunan HTI dan perkebunan besar. Bagian kedua menyampaikan konversi hutan alam oleh HPH, HTI dan perkebunan. Bagian ketiga mengupas analisis kebijakan pembangunan HTI dan perkebunan. Dalam bagian kesimpulan dirumuskan ringkasan penemuan dan rekomendasi perubahan kebijakan yang diperlukan.

\section{Pembangunan HTI dan Perkebunan}

\section{Hutan Tanaman Industri}

Pembangunan HTI dilaksanakan baik secara mandiri, maupun dikaitkan dengan hak pengusahaan hutan (HPH) yang sudah ada. Pembangunan HTI yang dilaksanakan secara mandiri dapat berupa HTI Pulp dan HTI Perkakas/ Pertukangan. Sedangkan pembangunan HTI yang dikaitkan dengan HPH dilaksanakan dengan menyertakan transmigran sebagai tenaga kerjanya. Pembangunan HTI ini disebut sebagai HTI-Transmigrasi yang biasanya menanam kayu perkakas/pertukangan.

Dari luas HTI yang dicadangkan yaitu 4,7 juta ha (Dephut 1997), luas HTI yang telah disetujui pemerintah sampai dengan Oktober 1998 adalah 4,6 juta ha, yang rinciannya dapat dilihat pada Tabel 1.

HTI yang sudah ditanami sampai dengan Oktober 1998 seluas 2 juta ha atau $45 \%$ dari luas HTI yang telah disetujui pemerintah (Lihat Tabel 1). Berdasarkan jumlah luas, pembangunan HTI Pulp menempati urutan teratas (68\%), disusul HTI Pertukangan (18\%), dan HTI Transmigrasi (14\%). Pertumbuhan pembangunan HTI Transmigrasi dibatasi oleh ketersediaan lahan transmigrasi baru. Namun demikian, permintaan lahan bagi pembangunan HTI Transmigrasi ini akan meningkat seiring dengan meningkatnya target program transmigrasi (resettlement), terutama di Kawasan Indonesia Timur. Dari sisi penggunaan dana reboisasi, HTI Pulp menyerap hampir $40 \%$ dalam pembiayaan pembangunan HTI, sedangkan HTI Pertukangan hanya menyerap 8\%.

Dari 98 unit HTI yang pembangunannya telah disetujui, 24 unit di antaranya dimiliki oleh 17 pemilik yang mencakup HTI seluas 3,4 juta ha atau 73\% dari seluruh luas HTI yang sudah disetujui (Dephutbun 1998a). Perkembangan HTI yang sangat pesat disebabkan oleh adanya insentif bantuan biaya pembangunan HTI yang berasal dari dana reboisasi.

Namun dalam kenyataannya 22 unit HTI yang terdiri dari 4 unit HTI pulp dan 18 unit HTI pertukangan dibangun tanpa insentif dari dana reboisasi. Salah satu direktur dari perusahaan kelompok ini yang diwawancarai, yang tidak bersedia disebut namanya, mengungkapkan alasannya

Tabel 1. Rekapitulasi Pembangunan Hak Pengusahaan HTI s/d Oktober 1998 (Dephutbun 1999).

\begin{tabular}{|c|c|c|c|c|c|}
\hline \multirow[t]{2}{*}{ No } & \multirow[t]{2}{*}{ Jenis } & $\begin{array}{c}\text { Jumlah } \\
\text { Permohonan } \\
\end{array}$ & $\begin{array}{c}\text { Jumlah yang } \\
\text { Disetujui }\end{array}$ & $\begin{array}{l}\text { Luas yang } \\
\text { Disetujui }\end{array}$ & $\begin{array}{l}\text { Luas yang } \\
\text { Sudah Ditanami }\end{array}$ \\
\hline & & \multicolumn{2}{|c|}{ (Unit) } & \multicolumn{2}{|c|}{ (ha) } \\
\hline \multirow[t]{5}{*}{1.} & HTI Pulp (23 unit ) & 23 & 18 & 3.128 .443 & 997.213 \\
\hline & - Prioritas & 13 & 13 & 2.605 .938 & 395.908 \\
\hline & - Menggunakan DR & 9 & 9 & 1.799 .162 & na \\
\hline & - Tanpa DR & 4 & 4 & 806.776 & na \\
\hline & - Nonprioritas & 10 & 5 & 522.505 & 601.305 \\
\hline \multirow[t]{3}{*}{2.} & HTI Pertukangan (52 unit) & 52 & 31 & 835.334 & 812.399 \\
\hline & - Menggunakan DR & 17 & 13 & 377.613 & na \\
\hline & - Tanpa DR & 35 & 18 & 457.721 & na \\
\hline 3. & HTI Transmigrasi (70 unit) & 70 & 49 & 640.441 & 266.007 \\
\hline \multicolumn{2}{|c|}{ JUMLAH } & 145 & 98 & 4.604 .218 & 2.075 .619 \\
\hline
\end{tabular}

DR = dana reboisasi; HTI Prioritas = diprioritaskan pemerintah, berupa HTI Pulp; na= data tidak tersedia. 
bahwa adanya subsidi dana reboisasi yang diikuti oleh masuknya Badan Usaha Milik Negara dalam manajemen perusahaan, menambah biaya manajemen perusahaan dan biaya lainnya untuk urusan administratif yang berkaitan dengan pencairan dana reboisasi. Di samping itu perusahaan-perusahaan yang tidak bersedia menerima subsidi sudah mempunyai kepastian pasar hasil kayu dari HTInya, terutama untuk industri perkayuan yang sudah ada maupun untuk ekspor.

\section{Perkebunan}

Luas areal perkebunan di Indonesia, baik perkebunan besar maupun perkebunan rakyat, cenderung meningkat dari tahun ke tahun. Dari seluruh komoditas utama perkebunan (karet, kopi, teh, kelapa, kakao, tebu dan kelapa sawit), komoditas karet dan kelapa sawit adalah areal pertanaman yang terluas. Pertambahan luas yang paling spektakuler dialami oleh perkebunan kelapa sawit yang dalam 10 tahun terakhir luasnya meningkat rata-rata $14 \%$ per tahun, jauh di atas peningkatan perkebunan karet yang hanya rata-rata $2 \%$ per tahun (Susila 1998). Pada tahun 1986, luas perkebunan kelapa sawit baru mencapai 606.800 ha, tetapi pada tahun 1997 meningkat pesat menjadi 2,25 juta ha. Saat ini pusat perkebunan kelapa sawit terletak di propinsi Sumatera Utara (905.000 ha), propinsi Riau (544.700 ha), propinsi Kalimantan Barat (211.400 ha) dan propinsi Sumatera Selatan (206.000 ha). Di masa mendatang akan dikembangkan secara cepat di Kalimantan Timur, Sulawesi dan Irian Jaya (Susila 1998).

Luas seluruh areal perkebunan kelapa sawit masih di bawah perkebunan karet yang mencapai 3,5 juta ha pada tahun 1997. Namun struktur pemilikan pada perkebunan kelapa sawit terbalik dengan perkebunan karet. Perkebunan karet pemilikannya didominasi oleh perkebunan rakyat (83\%), tetapi perkebunan kelapa sawit dimiliki oleh perusahaan besar, baik milik negara maupun milik swasta yang mendominasi luas lahan dengan pangsa 66\% (Susila 1998).

Perkebunan kelapa sawit mulai berkembang pesat sejak tahun 1978 (Lihat Gambar 1), dengan laju pertumbuhan luas per tahun yang sangat tinggi, yaitu 21,7\% (perkebunan swasta), 2,9\% (perkebunan negara) dan 19,3\% (perkebunan rakyat) (Susila 1998). Untuk mendapatkan lahan yang dibutuhkan, cara yang paling sering ditempuh oleh pengusaha adalah melakukan konversi kawasan hutan, karena mekanisme untuk (1967-1997). mendapatkannya relatif mudah dan mereka memperoleh keuntungan dari hasil tebangan kayu. Dengan demikian dapat dikatakan bahwa hampir seluruh pertanaman kelapa sawit yang ada sekarang merupakan areal pertanaman baru (new planting) dari areal hutan produksi yang dapat dikonversi.

Gambar 1. Perkembangan Luas Perkebunan Kelapa Sawit dan Karet di Indonesia

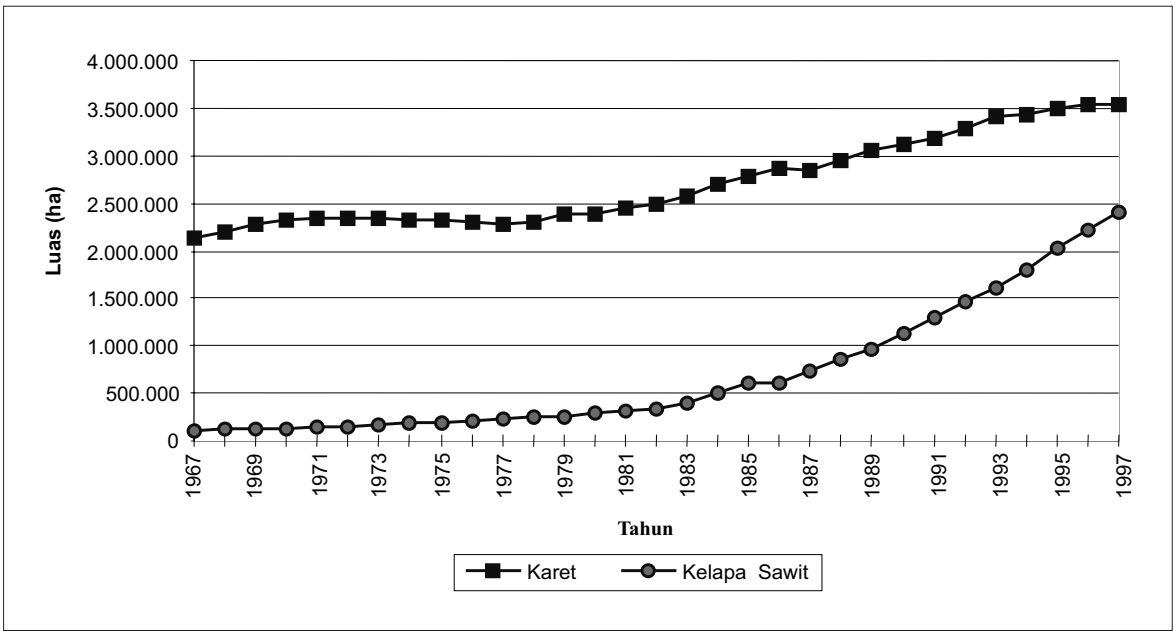

Laju pertumbuhan areal perkebunan karet rakyat hanya mencapai 2,2\% per tahun (1986-1996), sedangkan untuk perkebunan kopi rakyat pertumbuhannya hanya 2,3\% untuk periode yang sama. Di samping laju pertumbuhan areal yang rendah, perkebunan rakyat biasanya tidak dibangun pada areal hutan produksi. Para pekebun kecil umumnya memanfaatkan lahan kritis ${ }^{2}$, hutan sekunder dan bahkan memanfaatkan kebun tua (replanting). Perkebunan karet rakyat merupakan pertanaman tradisional masyarakat, terutama di Sumatera dan Kalimantan, sedangkan kopi banyak diusahakan di Lampung, Sumatera Selatan dan Sulawesi Selatan. Perkembangan produksi minyak sawit, karet dan kopi Indonesia (1987-1997) dapat dilihat pada Gambar 2.

Gambar 2. Perkembangan Produksi Minyak Sawit, Karet dan Kopi Indonesia (1987-1997).

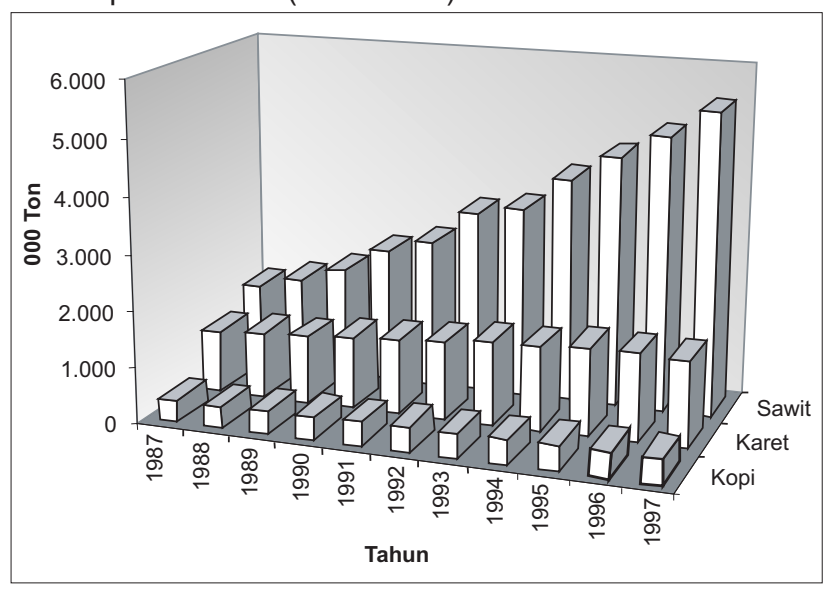


Perkembangan perkebunan kelapa sawit sangat cepat, namun berkurang sejak awal pertengahan tahun 1998. Salah satu penyebabnya adalah tingginya pajak ekspor, berkurangnya minat investor asing akibat kondisi politik yang tidak stabil, dan takut tingginya pasokan. Di tengahtengah kondisi ini, pertumbuhan kelapa sawit pada pertengahan 1998 adalah seperti berikut. Dengan tingkat produktivitas 18-21 ton TBS (tandan buah segar)/ha/ tahun, usaha ini mempunyai nilai Internal Rate of Return sampai $24-43 \%$. Di samping itu prospek minyak sawit mentah atau CPO (crude palm oil) juga sangat cerah. Untuk konsumsi domestik Indonesia, diperkirakan meningkat dengan laju pertumbuhan $8-10 \%$ per tahun pada periode 1995-2000 dan 5-7\% per tahun pada periode 2000-2005 (Arifin dan Susila 1998). Tingkat konsumsi minyak sawit dunia akan meningkat sebesar $5 \%$ per tahun antara tahun 1995-2000 dan pada tahun 2000 diproyeksikan konsumsi akan mencapai 18,2 juta ton, walaupun harga minyak sawit diproyeksikan menurun menjadi US\$ 415/ton pada tahun 2000 (Susila 1997).

Pada awal 1998 terdapat 50 perusahaan asing yang sedang melaksanakan pembangunan perkebunan kelapa sawit dengan investasi US\$ 3 miliar. Rencana perkebunan yang akan dikelola seluas 926.650 ha di Sumatera, Kalimantan, Sulawesi, dan Irian Jaya. ${ }^{3}$ Khusus untuk Propinsi Riau dan Sumatera Utara, pemerintah telah menyatakan daerah ini telah tertutup untuk investasi baru pengembangan perkebunan. ${ }^{4}$ Perusahaan asing yang sangat berambisi untuk mengembangkan perkebunan kelapa sawit di Indonesia adalah Malaysia. Hal ini disebabkan keterbatasan lahan untuk perkebunan kelapa sawit di Malaysia dan letak Indonesia yang paling dekat dengan lokasi fasilitas pabrik pengolahan di Malaysia.

Investor asing lainnya seperti dari Inggris dan Singapura sudah mengincar perkebunan milik negara yang kinerjanya baik. Pemerintah Indonesia memang bermaksud melakukan program privatisasi perkebunan negara dengan menjual sebagian saham kepada pihak swasta nasional maupun asing. Akan tetapi, agar pihak asing tidak menjadi pemegang saham mayoritas, pemerintah tidak menjual keseluruhan saham, karena yang dibutuhkan perkebunan hanya pengembangan produk derivatif dan jaringan pemasaran internasional. ${ }^{5}$

Untuk investor dalam negeri, keinginan berinvestasi di perkebunan kelapa sawit tidak terbatas pada perusahaan yang sudah biasa mengelola perkebunan, tetapi juga pada perusahaan lain seperti perusahaan kehutanan milik negara. PT. INHUTANI $\mathrm{III}^{6}$ misalnya, sudah menargetkan untuk membangun perkebunan kelapa sawit seluas 500 hingga 1.000 ha per tahun. ${ }^{7}$ Sementara itu PT INHUTANI I juga akan memasuki bisnis perkebunan, terutama tanaman karet dan kelapa sawit. Pada akhir Februari 1998, Menhutbun secara resmi telah mengizinkan Perum Perhutani dan PT Inhutani I s/d V melakukan ekspansi ke sektor perkebunan seperti kelapa sawit. ${ }^{8}$ Alasannya adalah usaha hutan merupakan investasi jangka panjang. Sedangkan perkebunan merupakan investasi jangka pendek yang diharapkan bisa memperbaiki cashflow Badan Usaha Milik Negara tersebut. ${ }^{9}$

Banyak perusahaan Indonesia yang belum mempunyai pengalaman di bidang perkebunan mencoba berbisnis kelapa sawit. Pada umumnya mereka memanfaatkan skema kredit khusus untuk pengembangan perkebunan rakyat dengan pola kemitraan, misalnya Pola Perusahaan Inti Rakyat-Transmigrasi (PIR-Trans) dan Kredit Koperasi Primer untuk Anggota (KKPA). Walaupun perusahaan besar mempunyai beban harus bermitra dan membina petani, dengan menggunakan pola-pola tersebut mereka berkesempatan untuk menjadi kontraktor pembangunan kebun milik petani, dapat memanfaatkan kayu tebangan hutan dan mendapatkan fee khusus untuk pengurusan kredit petani. Berbagai kalangan menyebutkan bahwa dengan mekanisme kerja seperti ini, perusahaan besar tidak membantu petani, tetapi mereka justru memanfaatkan skema kredit petani. ${ }^{10}$

Meskipun perkembangan investasi perkebunan melemah, terdapat indikasi bahwa investasi sektor ini akan segera meningkat (Casson 1999). Diproyeksikan bahwa luas areal perkebunan kelapa sawit di Indonesia akan mencapai 2,97 juta ha pada tahun 2000. Sampai dengan tahun 1997, persetujuan dan pelepasan hutan produksi untuk perkebunan sudah mencapai 6,7 juta ha. Luas ini belum termasuk luas permohonan pembangunan perkebunan yaitu 9 juta ha (Dephutbun 1998a).

\section{Konversi Hutan Alam}

Sejak dilaksanakannya padu serasi antara TGHK dan RTRWP, kawasan hutan negara ${ }^{11}$ mengalami perubahan. Perbandingan data luas kawasan hutan negara tahun 1984 dan 1997 menunjukkan bahwa secara nasional kawasan hutan lindung bertambah luasnya dari 29,3 juta ha menjadi 34,6 juta ha. Kawasan hutan konservasi tetap luasnya, sedangkan kawasan hutan produksi menurun luasnya dari 64 juta ha menjadi 58,6 juta ha. Sementara itu hutan konversi yang digunakan untuk berbagai kepentingan pembangunan perkebunan, transmigrasi, dll. terus mengalami penurunan dari seluas 30 juta ha pada tahun 1984 menjadi 8,4 juta ha pada tahun 1997.

Sampai dengan Juni 1998, kawasan hutan produksi dan konversi tersebut di atas telah dialokasikan untuk HPH seluas 69,4 juta ha, dan dicadangkan untuk HTI seluas 4,7 juta ha ${ }^{12}$ serta untuk perkebunan besar (bukan kebun rakyat) seluas juta 3 ha. Menurut Peraturan Pemerintah No. 21 Tahun $1970^{13}$ dan No. 9 Tahun 1990, pembangunan HPH dan HTI dilaksanakan di dalam kawasan hutan 
produksi yang dinyatakan sebagai kawasan hutan tetap (permanent forest). Sedangkan pembangunan perkebunan dilaksanakan di dalam hutan konversi.

Menurut hasil perhitungan dari berbagai studi kelayakan, di dalam kawasan HTI terdapat hutan alam yang masih produktif rata-rata sebesar $22 \%$ dari seluruh kawasan hutan yang dikelolanya. ${ }^{14}$ Dengan demikian, hutan alam yang dikonversi dalam pembangunan HTI sampai dengan Juni 1998 adalah seluas 1 juta ha (22\% x 4,6 juta ha).

Sementara itu meskipun kawasan hutan lindung maupun hutan konservasi tidak diijinkan diubah fungsinya, di beberapa lokasi terdapat perambahan hutan oleh perkebunan, hutan tanaman, maupun perladangan oleh penduduk setempat. Kondisi perubahan kawasan hutan tahun 1984 - 1997 disajikan dalam Tabel 2.

\section{Kerusakan Hutan Alam oleh HPH}

Data dari Departemen Kehutanan dan Perkebunan ${ }^{15}$ menunjukkan bahwa sampai dengan Juni 1998 areal hutan yang dialokasikan untuk 651 HPH seluas 69,4 juta ha. Dari 69,4 juta ha ini 34 juta ha $(49 \%)$ di antaranya dikelola oleh $291 \mathrm{HPH}$ yang sedang menjalankan jangka waktu konsesi pertamanya (20 tahun yang pertama). Sedangkan 359 unit HPH lainnya, dengan luas 35,5 juta ha (51\%), jangka waktu konsesi pertamanya telah berakhir.

Data di atas dan rincian dalam Gambar 3 bagian bawah menunjukkan bahwa kerusakan hutan oleh HPH sampai Juni 1998 adalah 16,57 juta ha, yang oleh pemerintah dialihfungsikan, direhabilitasi, serta dicadangkan untuk keperluan lain yang belum ditetapkan. Untuk lebih jelasnya, perubahan status HPH dan alih fungsi hutan yang dikelola HPH dapat dilihat pada Gambar 3.

Tabel 2. Perubahan Kawasan Hutan Negara dan Alih Fungsi Hutan di Indonesia (1984 - 1997).

\begin{tabular}{|c|c|c|}
\hline $\begin{array}{l}\text { Kategori Penatagunaan Kawasan } \\
\text { Hutan Negara }\end{array}$ & $\begin{array}{l}\text { Perubahan Fungsi Hutan yang } \\
\text { Diijinkan }\end{array}$ & Perubahan Fungsi Hutan yang Sudah Terjadi \\
\hline $\begin{array}{l}\text { Hutan Lindung } \\
1984=29,3 \text { juta ha } \\
1997=34,6 \text { juta ha }\end{array}$ & $\begin{array}{l}\text { [Tidak diijinkan diubah } \\
\text { fungsinya] }\end{array}$ & $\begin{array}{l}\text { - Setelah tahun } 1997 \text { ketika padu serasi antara } \\
\text { TGHK dan RTRWP mulai dilakukan, jumlah } \\
\text { kawasan hutan lindung naik menjadi 34,6 juta ha. } \\
\text { Berdasarkan hasil evaluasi kawasan HPH, } \\
\text { kawasan hutan lindung dan konservasi } \\
\text { bertambah seluas } 1,31 \text { juta ha (lihat Gambar 3, } \\
\text { pada kotak perubahan fungsi kawasan HPH). } \\
\text { - Terdapat perambahan, tetapi datanya tidak } \\
\text { tersedia. }\end{array}$ \\
\hline $\begin{array}{l}\text { Hutan Konservasi } \\
\text { (Suaka Alam, Taman Nasional, dll) } \\
1984=1997=19 \text { juta ha }\end{array}$ & $\begin{array}{l}\text { [Tidak diijinkan diubah } \\
\text { fungsinya] }\end{array}$ & $\begin{array}{l}\text { - Terdapat perambahan, tetapi datanya tidak } \\
\text { tersedia. }\end{array}$ \\
\hline $\begin{array}{l}\text { Hutan Produksi } \\
1984=64 \text { juta ha; } 1997= \\
58,6 \text { juta ha } \\
\text { Terdiri dari: } \\
\text { - Hutan Produksi Tetap } \\
1984=1997=34 \text { juta ha } \\
\text { - Hutan Produksi Terbatas }{ }^{a} \\
1984=30 \text { juta ha } \\
1997=24,6 \text { juta ha }\end{array}$ & $\begin{array}{l}\text { Dikelola HPH seluas } 69,4 \\
\text { juta ha. }{ }^{{ }^{2}} \\
\text { Rencana pembangunan } \\
\text { HTI seluas } 4,7 \text { juta ha } \\
\text { Dalam kawasan HTI } \\
\text { dapat dibangun tanaman } \\
\text { perkebunan }\end{array}$ & $\begin{array}{l}\text { Sisa hutan yang belum ditebang oleh HPH di } \\
\text { hutan produksi tetap seluas } 9,4 \text { juta ha, hutan } \\
\text { produksi terbatas seluas } 12,3 \text { juta ha. Hutan } \\
\text { yang telah rusak di kawasan HPH seluas } 16,57 \\
\text { juta ha. } \\
\text { - } \\
\text { Sampai Juni } 1998 \sim \text { sudah dialokasikan untuk } \\
\text { HTI seluas } 4,6 \text { juta ha. Pembangunan HTI ini } \\
\text { diperkirakan dilakukan dengan mengkonversi } \\
\text { hutan alam primer seluas } 1 \text { juta ha. } \\
\text { - Sampai Maret } 1998 \text {, terdapat perusahaan } \\
\text { perkebunan di dalam hutan produksi seluas } \\
60.000 \text { ha. }\end{array}$ \\
\hline $\begin{array}{l}\text { Hutan Konversi } \\
1984=30 \text { juta ha } \\
1997=8,4 \text { juta ha }\end{array}$ & $\begin{array}{l}\text { Dialihfungsikan } \\
\text { seluruhnya } \\
\text { Tahun } 1997 \sim \text { Jumlah } \\
\text { hutan konversi yang } \\
\text { masih tersisa seluas } 8,4 \\
\text { juta Ha. Hutan konversi } \\
\text { ini masih berupa hutan } \\
\text { alam primer. }\end{array}$ & $\begin{array}{l}\text { - Jumlah hutan untuk perkebunan sampai dengan } \\
\text { - Group (holding company) } \sim 2,8 \text { juta ha } \\
\text { - Nongroup (perusahaan tunggal) } \sim \text { 3,9 juta ha } \\
\text { - Total (Group dan Nongroup) 6,7 juta ha } \\
\text { - Perkiraan jumlah defisit/surplus jika seluruh } \\
\text { perusahaan perkebunan beroperasi dapat dilihat } \\
\text { pada Tabel } 3 \text {. }\end{array}$ \\
\hline
\end{tabular}

a Hutan produksi terbatas lebih curam dan mempunyai kelerengan lebih terjal daripada hutan produksi tetap, sehingga jumlah kayu yang ditebang lebih dibatasi. Dalam peraturan Tebang Pilih Tanam Indonesia (TPTI), batas diameter kayu yang ditebang di hutan produksi terbatas minimal 60 $\mathrm{cm}$, sedangkan di hutan produksi tetap diameter yang boleh ditebang dibatasi paling kecil sebesar $50 \mathrm{~cm}$.

b Kawasan hutan yang dikelola HPH juga berupa hutan konversi.

c Hutan yang telah rusak di dalam kawasan HPH yang akan direhabilitasi seluas 9,54 juta ha, pencadangan areal dan belum ada alokasi seluas 5,12 juta ha, serta dilakukan alih fungsi untuk hutan tanaman seluas 0,71 juta ha, perkebunan seluas 30.000 ha dan transmigrasi seluas 80.000 ha. 
Gambar 3. Perubahan Status HPH dan Alih Fungsi Hutan yang Dikelola HPH s/d Juni 1998 (Diolah dari data Dephutbun, 1998).

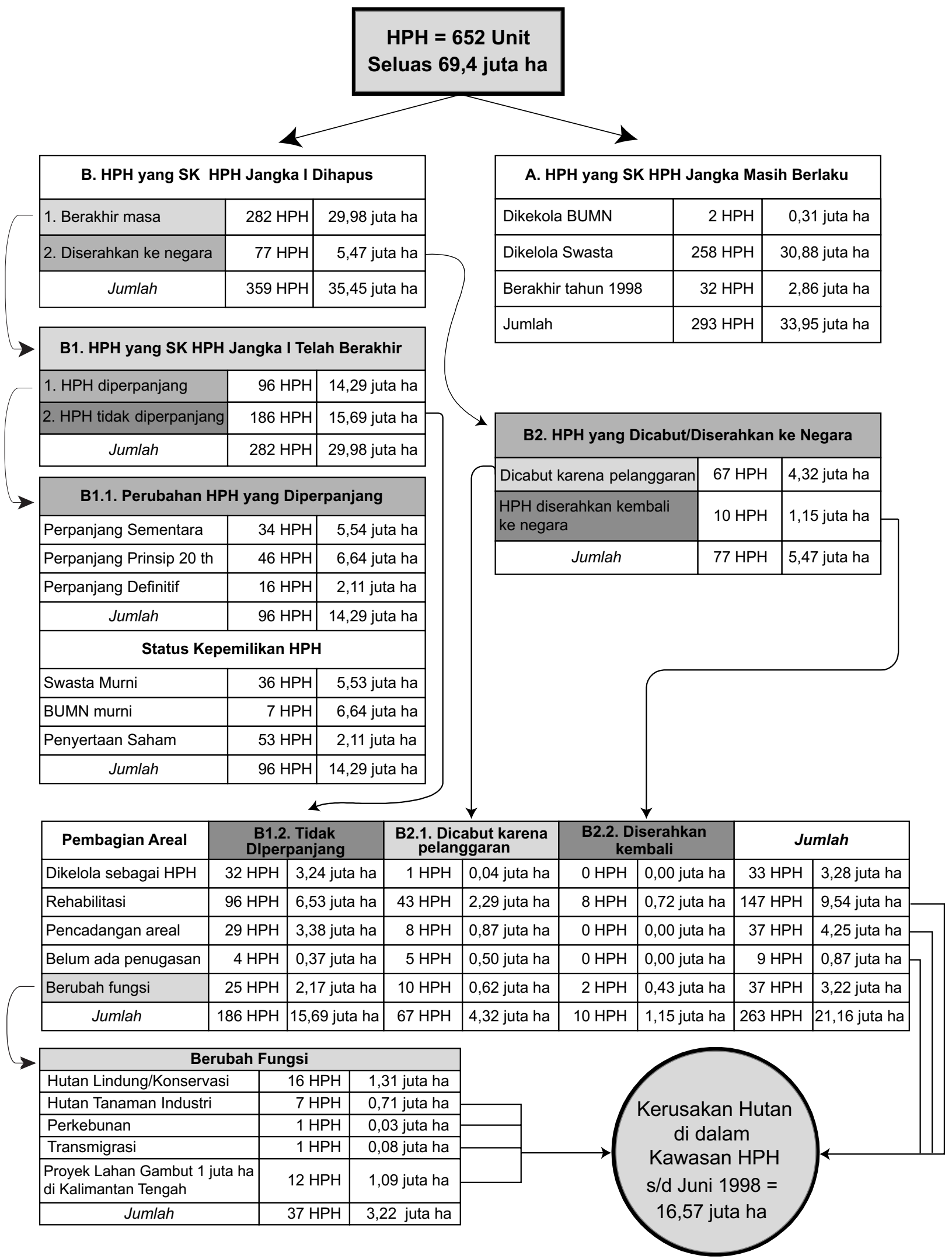


Dalam rangka alih fungsi tersebut PT. INHUTANI I mencari mitra usaha dengan pengusaha swasta untuk mengembangkan kebun kelapa sawit di atas lahan HPH yang telah dicabut haknya dan dilimpahkan pengurusannya ke PT INHUTANI I. Sampai Maret 1998, PT. INHUTANI I telah bermitra dengan lima perusahaan swasta yang semua berada di Kawasan Indonesia Timur. Empat di antaranya dengan PT. Texmaco di Maluku seluas 60.000 ha. Selain itu juga dengan PT. Gmelina Lestari, PT. Surya Dumai Group dan PT. Komismar Maju Agro yang belum diketahui luasnya. ${ }^{16}$

\section{Alokasi Hutan Konversi}

Luas hutan produksi yang dapat dikonversi terus mengalami penurunan dan pada akhir tahun 1997 mencapai 8,4 juta ha. Perkebunan yang akan dibangun di hutan konversi ini, untuk tahap persetujuan dan pelepasan adalah seluas 6,8 juta ha. ${ }^{17}$ Dari luas ini khusus untuk perluasan perkebunan melalui pola PIR mencapai 938.763 ha (Ditjenbun 1998).
Luas rencana pembangunan perkebunan ini belum termasuk tahap permohonan yang sampai dengan Juni 1998 mencapai 9 juta ha. ${ }^{18}$ Jika permintaan investor perkebunan ini seluruhnya dipenuhi, tanpa memperhitungkan tahap permohonan, propinsi-propinsi di Sumatera dan Kalimantan akan mengalami defisit hutan konversi. Demikian pula jika tahap permohonan seluas 9 juta ha pada akhirnya diimplementasikan di lapangan, yang sebagian besar diarahkan ke Kawasan Indonesia Timur, juga akan menghadapi masalah yang sama karena di wilayah Maluku dan Irian Jaya pun, hutan konversi hanya berjumlah 4,6 juta ha. Kenyataan ini menunjukkan betapa tingginya potensi konversi hutan tetap (permanent forest) di masa yang akan datang.

Tabel 3 menunjukkan perkembangan luas hutan konversi dari tahun 1981-1997 serta potensi surplus/defisit hutan konversi bila perusahaan perkebunan sudah beroperasi pada tahap persetujuan dan pelepasan.

Tabel 3. Perkembangan Luas Hutan Konversi (1981-1997) dan Surplus/Defisit Hutan Konversi bila Seluruh Perusahaan Perkebunan Tahap Persetujuan dan Pelepasan Beroperasi.

\begin{tabular}{|c|c|c|c|c|c|c|c|c|c|c|}
\hline \multirow{3}{*}{ Propinsi/Region } & \multirow{2}{*}{\multicolumn{4}{|c|}{$\begin{array}{c}\begin{array}{c}\text { Perkembangan Luas Hutan } \\
\text { Konversi }^{(\mathrm{a})}\end{array} \\
(1.000 \mathrm{ha})\end{array}$}} & \multicolumn{4}{|c|}{ Perusahaan Perkebunan Skala Besar $(1.000 \text { ha })^{(b)}$} & \multirow{3}{*}{ Jumlah } & \multirow{3}{*}{$\begin{array}{r}\text { +/- Hutan } \\
\text { Konversi } \\
\text { (1.000 ha) }\end{array}$} \\
\hline & & & & & \multicolumn{2}{|c|}{ Nongrup } & \multicolumn{2}{|c|}{ Grup $^{(c)}$} & & \\
\hline & 1981 & 1984 & 1990 & 1997 & Persetujuan & Pelepasan & Persetujuan & Pelepasan & & \\
\hline DI. Aceh & 188 & 193 & 848 & 95 & 136,35 & 120,62 & 5,78 & 6,46 & 269,21 & -174 \\
\hline Sumut & 532 & 254 & 254 & 37 & 65,40 & 46,90 & 56,61 & 26,24 & 195,15 & -158 \\
\hline Sumbar & 597 & 438 & 438 & 189 & 56,53 & 60,60 & - & - & 117,12 & 72 \\
\hline Riau & 2773 & 1754 & $\left({ }^{*}\right)$ & 335 & 837,84 & 717,28 & 719,94 & 330,02 & 2605,07 & -2270 \\
\hline Jambi & - & 1013 & 727 & - & 105,81 & 98,48 & 136,51 & 124,22 & 465,02 & -465 \\
\hline Sumsel & 2421 & 1186 & 1186 & 774 & 123,24 & 17,77 & 11,50 & 11,51 & 164,03 & 610 \\
\hline Bengkulu & 23 & 194 & 179 & 120 & - & - & - & - & - & 120 \\
\hline Lampung & 573 & - & 153 & 137 & 68,20 & 74,78 & 57,69 & 64,27 & 264,94 & -128 \\
\hline SUMATERA & 7107 & 5032 & 3785 & 1687 & 1393,35 & 1136,43 & 988,03 & 562,72 & 4080,53 & -2394 \\
\hline Bali & 4 & - & $\left({ }^{*}\right)$ & $\left({ }^{*}\right)$ & - & - & - & - & - & - \\
\hline NTB & 224 & 196 & $\left({ }^{*}\right)$ & $\left({ }^{\star}\right)$ & - & - & - & - & - & - \\
\hline NTT & 278 & 2802 & 181 & 181 & - & - & - & - & - & 181 \\
\hline Timor Timur & 45 & 10 & 10 & - & - & - & - & - & - & - \\
\hline $\begin{array}{l}\text { BALI, NUSRA } \\
\text { dan TIMTIM }\end{array}$ & 551 & 3008 & 191 & 181 & - & - & - & - & - & 181 \\
\hline Kalbar & 1323 & 1509 & 1509 & 534 & 94,76 & 58,84 & 49,40 & 24,60 & 227,60 & 306 \\
\hline Kalteng & 6068 & 3000 & $\left({ }^{*}\right)$ & $\left({ }^{*}\right)$ & 267,37 & 267,99 & 159,36 & 82,46 & 777,18 & -777 \\
\hline Kalsel & 1331 & 285 & 285 & 265 & - & - & 126,18 & 101,68 & 227,86 & 37 \\
\hline Kaltim & 5513 & 3500 & $\left({ }^{*}\right)$ & $\left({ }^{\star}\right)$ & 309,60 & 207,01 & 254,39 & 52,68 & 823,67 & -824 \\
\hline KALIMANTAN & 14235 & 8294 & 1794 & 799 & 671,73 & 533,83 & 589,32 & 261,42 & 2056,30 & -1257 \\
\hline Sulut & 304 & 699 & 294 & 35 & 8,00 & 0,59 & - & - & 8,59 & 26 \\
\hline Sulteng & 1028 & 335 & 242 & 269 & 76,57 & 61,33 & 59,95 & 19,12 & 216,97 & 52 \\
\hline Sulsel & 165 & 259 & 259 & 259 & 41,40 & 15,70 & 30,35 & 40,77 & 128,22 & 131 \\
\hline Sultra & 669 & 699 & 699 & 212 & 13,12 & - & - & - & 13,12 & 199 \\
\hline SULAWESI & 2166 & 1992 & 1494 & 775 & 139,09 & 77,62 & 90,30 & 59,89 & 366,89 & 408 \\
\hline MALUKU & 1030 & 436 & $\left(^{*}\right)$ & 2305 & -- & -- & - & - & & 2305 \\
\hline IRIAN JAYA & 7123 & 11775 & 11775 & 2671 & 11,19 & 3,28 & 257,81 & 20,51 & 292,78 & 2378 \\
\hline INDONESIA & 33635 & 30537 & 19039 & 8418 & 2215,35 & 1751,16 & 1925,46 & 904,53 & 6796,50 & 1621 \\
\hline
\end{tabular}

(a). Diolah dari data Biro Pusat Statistik (berbagai tahun); (b). Diolah dari data Dephutbun (1998); (c). Perkebunan Nongrup adalah perusahaan perkebunan yang tidak memiliki holding company, sedangkan perkebunan grup memiliki holding company; (*). Pada propinsi-propinsi ini lokasi hutan produksi yang dapat dikonversi dan areal penggunaan lainnya belum dapat dipisahkan. 


\section{Perambahan Hutan Konservasi dan Hutan Lindung}

Pembangunan HTI dan perkebunan juga sering tumpang tindih dengan kawasan konservasi. Sebagai contoh Taman Nasional Bukit Tigapuluh seluas 127.698 ha yang membentang di antara Propinsi Jambi dan Riau, telah terancam kelestariannya oleh dua perkebunan besar, yaitu PT Sumatera Makmur Lestari seluas 8.000 ha dan PT Arvena Sepakat seluas 5.450 ha. ${ }^{19}$ Demikian juga yang terjadi pada Perkebunan Inti Rakyat Blambangan Umpu Lampung yang merambah areal hutan lindung seluas 216 ha (Ditjenbun 1998). Di Kalimantan Timur terdapat 21 kasus pembangunan perkebunan menggunakan kawasan hutan lindung (Sunderlin 1998).

\section{Analisis Kebijakan Pembangunan HTI dan Perkebunan}

\section{Reaksi Pengusaha: Orientasi pada kayu hasil pembukaan hutan alam}

Kebijakan alokasi dan konversi hutan alam telah mendorong swasta bereaksi sangat cepat untuk menanamkan modalnya, baik untuk pembangunan HTI maupun perkebunan. Jika dilihat dari kepemilikannya, satu holding company dapat mempunyai perusahaan HPH, HTI dan perkebunan sekaligus. Dari berbagai laporan, holding company seperti Raja Garuda Mas, Astra, Kalimanis, Salim Group, Sinar Mas, Uniseraya Group, Texmaco, dan Barito Pacific mempunyai perusahaan-perusahaan HPH, HTI dan perkebunan. ${ }^{20}$

Perkembangan investasi yang cepat di atas juga diikuti oleh hal-hal yang menyimpang. Setelah para pengusaha mendapat areal, terbukti ada yang tidak melaksanakan atau menunda pelaksanaan pembangunan, dengan faktafakta sebagai berikut:

1. Evaluasi pembangunan HTI sampai Januari 1996 menunjukkan bahwa realisasi penanaman dibandingkan dengan rencana yang telah ditetapkan sebesar 46\% untuk HTI Pulp dan 13\% untuk HTI Kayu Perkakas (Dephut 1996). HTI yang dalam kurun waktu 8 tahun diharapkan oleh pemerintah mampu memasok kebutuhan bahan baku kayu bagi industri pulp menggantikan pasokan kayu dari hutan alam, ternyata sejak dikembangkan mulai awal Pelita V sampai Juli 1997 secara keseluruhan realisasi penanamannya baru mencapai $23,1 \%$ dari rencana. ${ }^{21}$ Hal ini menyebabkan industri pulp dan perkayuan pada umumnya masih selalu mengandalkan hutan alam sebagai sumber bahan bakunya. Akibatnya pencurian kayu dari hutan alam terus meningkat.
2. Ketua Badan Koordinasi Penanaman Modal Daerah Propinsi Bengkulu, Ir Syahrir AB MSc mengatakan, sebanyak 10 perusahaan perkebunan di Bengkulu akan dicabut izin lokasinya, karena para investor tidak mengolah lahan yang telah diberikan. Kesepuluh investor ini terdapat di Kabupaten Bengkulu Selatan sebanyak 7 perusahaan (61.000 ha), Bengkulu Utara 1 perusahaan ( 3.150 ha), dan di Kabupaten Rejanglebong 2 perusahaan (2.350 ha). ${ }^{22}$

3. Pegawai Dinas Perkebunan Propinsi Riau mengatakan, izin pelepasan kawasan hutan yang dimiliki puluhan perusahaan perkebunan yang ternyata kemudian menelantarkan lahanya, akan segera dicabut dan dialihkan ke perusahaan lain. ${ }^{23}$

4. Pemerintah daerah Kalimantan Timur juga akan kembali mencabut 50 dari 105 izin lokasi investor perkebunan yang bermaksud membuka proyeknya di daerah ini. Ancaman ini disampaikan, karena banyak pemodal yang dinilai tidak serius dan bermaksud hanya mengeruk keuntungan dari izin yang telah diberikan. Ancaman yang sama juga sudah pernah dilaksanakan oleh Pemerintah Daerah sebelumnya pada awal tahun 1998, dengan mencabut 93 izin lokasi. Tindakan mereka ini dengan sendirinya sangat merugikan kepentingan pembangunan daerah. Bukan saja hasil hutan berupa kayunya habis, juga banyak pengusaha lain yang bisa jadi lebih serius, menjadi tertutup peluang usahanya di Kalimantan Timur. ${ }^{24}$

Hal lain adalah dampak adanya kebijakan yang menganjurkan pembangunan hutan tanaman dipadukan dengan pembangunan perkebunan di dalam kawasan hutan produksi yang dilakukan oleh Badan Usaha Milik Negara. Di samping untuk meningkatkan kinerja ekonomi perusahaan, alasan pemerintah lainnya untuk melibatkan perusahaan negara kehutanan dalam usaha perkebunan adalah sebagai langkah strategis untuk mengamankan hutan. Namun, pada kenyataannya langkah-langkah seperti itu hampir selalu mengorbankan hutan alam untuk membangun perkebunan kelapa sawit. Dengan demikian, motivasi badan usaha milik negara untuk terjun dalam bisnis kelapa sawit tidak berbeda dengan perusahaanperusahaan swasta di atas, yaitu mencari keuntungan ekonomi ganda, dari usaha kelapa sawit maupun perolehan kayu dari hutan alam saat pembukaan lahan.

\section{Sengketa Agraria dan Dampak Sosial}

Meskipun studi kelayakan dilakukan sebagai syarat pembangunan HTI dan perkebunan, acuan TGHK, RTRWP maupun hasil padu serasinya ternyata tidak menyelesaikan masalah terjadinya sengketa agraria. 
Pembangunan perkebunan di Sumatera Selatan, misalnya, dalam pelaksanaannya telah menggusur kebun rakyat. Sedikitnya $41.155,5$ ha lahan perkebunan rakyat milik 4.101 kepala keluarga di delapan kabupaten di Propinsi Sumatera Selatan telah diambil paksa oleh 13 perusahaan perkebunan daerah. Ke-13 perusahaan itu adalah PT Barito Pasific Timber, PT Pakerin, PTPN VII, PT Mitra Ogan, PT Gunung Sawit Bina Lestari, PT London Sumatera, CV Harvelia, PT Bumi Arjo Makmur, PT Perjapin Prima, PT Tata Hamparan Eka Persada, PT Cipta Futura Plantation, PT Multradin Multi Maju, dan PT Surya Bumi Agro Langgeng. ${ }^{25}$

Dari 81 perusahaan perkebunan kelapa sawit, yang ada di Propinsi Sumatera Selatan, yang luas pencadangan arealnya 554.000 ha, seluruhnya terdapat masalah sengketa lahan dengan penduduk setempat. Lahan yang menjadi sengketa dalam perkebunan kelapa sawit mencapai 83 ribu ha atau $11 \%$ dari luas seluruhnya. Demikian pula untuk pembangunan HTI yang dilakukan oleh sebanyak 14 perusahaan, seluruhnya menghadapi konflik lahan dengan penduduk setempat. ${ }^{26}$ Dengan demikian saat ini Sumatera Selatan menghadapi 103 kasus sengketa tanah akibat pembangunan HTI dan perkebunan.

Dalam kondisi krisis ekonomi dan ketidakstabilan politik seperti sekarang ini timbul gerakan-gerakan antiHPH, HTI dan Perkebunan. Di beberapa tempat telah terjadi perusakan dan pencurian hasil HTI dan perkebunan, dengan contoh-contoh kasus berikut:

1. Aksi masa petani yang menduduki HTI milik PT Dharma Hutan Lestari di Gedongwani, Tanjungbintang, Lampung Selatan makin meluas. Ribuan petani terus membabati pohon, menimbunnya di puluhan tempat di tepi jalan untuk seterusnya dijual. ${ }^{27}$

2. Lahan-lahan PTPN II Sumatera Utara yang sengaja di-bera-kan untuk tanaman tembakau pada musim tanam 1999, 2000 dan 2001 mulai digarap oleh warga masyarakat yang tidak berhak menggarapnya. Para penggarap menjarah tandan buah segar sawit, kakao dan tebu milik PTPN II tersebut. ${ }^{28}$ Pencurian kelapa sawit milik PT Raya Padang Langkat diperkirakan mencapai 200 ha di kecamatan Besitang, Kabupaten Langkat, Sumatera Utara. ${ }^{29}$

3. Di kebun PTPN IV Sumatera, selama kurun waktu Januari-Juni 1998, telah terjadi pencurian 5793 kasus pencurian kelapa sawit sebanyak 6480 ton dan 450 kasus pencurian kakao sebanyak 30,5 ton. ${ }^{30}$ Menurut Sudjai Kartasasmita, Ketua Badan Kerjasama Perusahaan Perkebunan Sumatera, memburuknya keamanan di perkebunan, seperti pencurian tandan buah sawit dan pengkaplingan areal perkebunan oleh beragam masyarakat, telah menimbulkan ketidaktenangan suasana kerja di kebun baik bagi pimpinan maupun karyawan. ${ }^{31}$ Keadaan ini telah memaksa aparat keamanan menempatkan sekitar 900 personil Brimob di kebun-kebun milik perkebunan besar di Sumatera Utara.

4. Penjarahan tidak hanya terjadi di perkebunan besar, tetapi juga merambah ke perkebunan rakyat. Petani kopi dan lada di Lampung, selain kopi dan ladanya dijarah di kebun, hasil penjualannya juga menjadi sasaran perampokan. Tercatat dalam bulan JuliAgustus 1998 di Lampung terjadi 8 kasus perampokan yang menyebabkan kerugian ratusan juta rupiah. ${ }^{32}$

\section{Kontroversi Kebijakan HTI}

Setelah sekian lama HPH beroperasi, pemerintah dihadapkan pada dua kondisi yang saling kontradiktif. Pertama, banyak HPH yang hutannya rusak dan tidak diperpanjang serta pengelolaannya dilimpahkan kepada Badan Usaha Milik Negara (PT. INHUTANI), sehingga pemerintah harus melaksanakan mekanisme baru dalam upaya rehabilitasi hutan alam. Kedua, penerimaan devisa melalui ekspor kayu olahan, khususnya kayu lapis, serta daya serap tenaga kerja oleh HPH dan industri perkayuan harus dipertahankan.

Menghadapi kenyataan demikian, pembangunan HTI dianggap sebagai suatu solusi untuk meningkatkan produktivitas hutan alam, ${ }^{33}$ sehingga insentif pembangunan HTI diwujudkan. Insentif ini kenyataannya sangat menarik swasta, terutama adanya subsidi dari dana reboisasi. Namun demikian, karena pasokan kayu dari hutan alam terus 'melimpah' karena juga dipasok dari kayu ilegal - harga kayu HTI menjadi sangat murah, bahkan tidak ada pasarnya. ${ }^{34}$ Akibatnya, perusahaan HTI tidak pernah diperhitungkan layak secara finansial, jika ia mandiri. Oleh karena itu perhitungan kelayakan finansial selalu dilakukan dengan mengaitkan HTI dengan industri yang mengolah hasil kayunya. ${ }^{35}$

Kenyataan di atas terbukti telah dimanfaatkan oleh sejumlah pengusaha swasta untuk mendapatkan fasilitas pembangunan HTI yang tujuannya memperolah kayu dari hutan alam yang dijadikan lokasi HTI, serta memperoleh subsidi dari dana reboisasi. Menghadapi kenyataan demikian, pemerintah seharusnya melakukan perubahan sistem pengusahaan hutan alam produksi (HPH), sebagai penyebab utama rusaknya hutan alam. Perubahan ini tidak kunjung dilakukan karena pemerintah berkepentingan mempertahankan peran $\mathrm{HPH}$ untuk menunjang pendapatan negara. Oleh karena itu, dari visi 
pemerintah, kebijakan pembangunan HTI diinterpretasikan sebagai suatu jalan penyelesaian masalah. ${ }^{36}$ Rusaknya hutan alam di dalam kawasan HPH dikeluarkan dari kawasan HPH dan menjadi kawasan HTI, sehingga kinerja HPH seolah-olah tidak menurun akibat adanya kerusakan hutan di dalam kawasannya. Dengan kebijakan ini, sistem pengusahaan hutan alam produksi (HPH) dapat dipertahankan, karena terbebas dari buruknya kinerja yang terlihat dari hutan yang rusak.

Kebijakan pembangunan HTI di atas secara implisit melegitimasi kerusakan hutan alam yang dilakukan oleh HPH. Skenario pembangunan HTI tidak pernah ada, seandainya HPH mampu mengelola hutan alam dengan baik. Oleh karena itu tidak mengherankan jika kebijakan pembangunan HTI - yang formulasi subsidinya dirancang oleh suatu studi yang dibiayai Bank Pembangunan Asia - mendapat dukungan dari kalangan swasta.

Menurut pemerintah, dengan dimasukkannya dana reboisasi ke dalam anggaran pendapatan dan belanja negara (APBN), atas permintaan IMF, pembangunan HTI akan mengalami hambatan. Karena kredit yang ada dengan bunga paling rendah $12 \%$ akan membuat pembangunan HTI tidak layak secara finansial (Dephutbun 1998b).

Pernyataan pemerintah tersebut belum tentu benar, mengingat terdapat 22 perusahaan yang mengelola sekitar 1,2 juta ha HTI justru tidak menggunakan fasilitas subsidi dari dana reboisasi yang ditawarkan pemerintah. Salah satu direktur dari perusahaan kelompok ini, yang tidak bersedia disebut namanya, mengungkapkan bahwa adanya subsidi dana reboisasi yang diikuti oleh masuknya Badan Usaha Milik Negara dalam manajemen perusahaan justru meningkatkan inefisiensi perusahaan. Alasannya, biaya manajemen perusahaan dan biaya lainnya untuk urusan administratif yang berkaitan dengan pencairan dana reboisasi menjadi meningkat. Pada umumnya perusahaan-perusahaan yang tidak bersedia menerima subsidi sudah mempunyai kepastian pasar hasil kayu dari HTInya, terutama untuk industri perkayuan yang sudah ada maupun untuk ekspor.

Kenyataan di atas menunjukkan bahwa, bagi perusahaanperusahaan tertentu, adanya subsidi pembangunan HTI dianggap tidak memberikan manfaat karena biaya transaksinya ${ }^{37}$ lebih tinggi daripada manfaat subsidi yang diberikan. Oleh karena itu, dari sudut pandang ini, masuknya dana reboisasi ke dalam APBN yang meniadakan pinjaman dana reboisasi tanpa bunga bukanlah hambatan pembangunan HTI seperti yang dikatakan pemerintah. Karena apa yang terjadi di lapangan, hambatannya bukan pada suku bunga pinjaman yang tinggi, melainkan pada tingginya biaya transaksi.

\section{Kebijakan Tata Guna Hutan}

Masalah lain yang berkaitan dengan pembangunan HTI dan perkebunan adalah tidak mampunya TGHK dan RTRWP serta padu serasinya dalam menyelesaikan konflik penggunaan lahan. ${ }^{38}$ Seperti telah diuraikan di atas, masalah penggunaan lahan telah memicu konflik sosial. Meskipun jumlah luasnya relatif kecil dibandingkan luas HPH dan HTI, pembangunan perkebunan, khususnya kelapa sawit yang pertumbuhannya sangat cepat, mempunyai dampak sosial paling besar.

Masalah struktural seperti ini tidak dapat dipecahkan jika pemerintah tetap menggunakan perencanaan yang bersifat top down, karena ternyata pengesahan hasil padu serasi TGHK dan RTRWP hanya berlaku di atas kertas. Ironinya, meskipun model perencanaan partisipatif (bottom up) telah cukup lama diperkenalkan dan dipresentasikan di Departemen Kehutanan dan Perkebunan oleh berbagai pihak, sistem ini belum juga diadopsi dan diimplementasikan di lapangan. ${ }^{39}$

Meskipun terdapat Undang-Undang Tata Ruang No. 29 Tahun 1992, yang dijabarkan ke dalam RTRWP, secara de facto, Dephutbun memegang peran sangat penting dalam pelaksanaan alokasi hutan dan lahan. Interpretasi Undang-Undang Pokok Kehutanan (UUPK) No. 5 Tahun 1967 dengan melakukan claim seluruh hutan yang tidak dibebani hak milik menjadi hutan negara, telah menutupi realitas adanya hutan adat dan keberadaan masyarakat yang tinggal di dalam kawasan hutan negara. Akibatnya, peraturan pemerintah sebagai penjabaran UUPK tidak mengakomodasikan suatu proses yang memungkinkan adanya representasi masyarakat lokal.

Hambatan lain dalam pelaksanaan tata guna hutan ini adalah adanya kenyataan tingginya conflict of interest antara pihak-pihak yang ingin mempertahankan keberadaan hutan tetap dengan pihak-pihak yang menginginkan konversi hutan untuk penggunaan lain, seperti perkebunan dan HTI. Menurut penjelasan salah seorang pejabat Badan Inventarisasi Tata Guna Hutan dan Kebun, Dephutbun, yang tidak bersedia disebutkan namanya, pelaksanaan padu serasi antara TGHK dan RTRWP yang selama ini dilakukan cenderung ingin memperluas areal perkebunan besar di setiap propinsi. Hal ini antara lain karena adanya kelompok-kelompok usaha besar yang mempengaruhi pejabat daerah untuk mendukung investasi perkebunan di daerahnya.

\section{Perubahan Kebijakan di Era Reformasi}

Terjadinya krisis ekonomi dan reformasi ekonomi dan politik di Indonesia secara langsung atau tidak langsung meningkatkan potensi tekanan terhadap hutan alam, tetapi sekaligus juga memberi harapan perubahan-perubahan 
kebijakan fundamental yang diperkirakan dapat memperbaiki kelemahan-kelemahan pembangunan kehutanan dan perkebunan yang selama ini terjadi. ${ }^{40}$

Memperhatikan pelaksanaan perubahan kebijakan di lingkungan Dephutbun, tampaknya pengakuan hak-hak adat atas sumber daya hutan masih sulit diterima pemerintah. Di pihak lain orientasi kebijakan lebih diarahkan untuk melakukan redistribusi hak-hak pengusahaan atas kawasan hutan negara yang semula dimiliki oleh pengusaha besar ke perusahaan kecil dan koperasi, tanpa ada suatu konsep yang jelas tentang upaya penyelamatan keberadaan hutan alam. Kenyataan demikian ini menunjukkan adanya suatu kecenderungan bahwa perbaikan terhadap kelemahan-kelemahan pembangunan kehutanan dan perkebunan, yang diharapkan dapat meminimumkan degradasi hutan alam, masih jauh dari harapan.

\section{Ringkasan Penemuan dan Rekomendasi}

\section{Ringkasan Penemuan}

1. Kegagalan HPH dalam mengelola hutan, telah membuat pemerintah mencabut HPH-HPH yang hutannya telah rusak. Kawasan hutan yang rusak ini diklasifikasikan menjadi kawasan hutan sebagai areal pencadangan, areal yang peruntukannya belum ditetapkan, dan areal yang dialihfungsikan untuk penggunaan lain. Luas areal ini sebesar 8,3 juta ha. Jika areal ini ditambah dengan areal dalam kawasan HPH yang akan direhabilitasi seluas 9,5 juta ha, maka jumlah hutan yang rusak di dalam kawasan HPH sampai Juni 1998 seluas 16,57 juta ha. Jika rata-rata umur HPH 20 tahun, maka hutan yang rusak di dalam kawasan HPH, yang dialihfungsikan untuk penggunaan lain, rata-rata sebesar 828.500 ha per tahun. Dengan demikian, dalam rangka penyelamatan hutan alam, perbaikan kebijakan HPH memegang peranan sangat penting.

2. Dalam areal HTI terdapat hutan alam yang masih produktif rata-rata sebesar 22\% dari seluruh kawasan hutan yang dikelolanya. Dengan demikian, hutan alam yang dikonversi dalam pembangunan HTI sampai dengan Juni 1998 seluas 1 juta ha. Ini berarti bahwa dilihat dari hutan alam yang rusak, pembangunan HTI juga mempunyai peran cukup besar.

3. Pembangunan perkebunan telah mengkonversi hutan alam yang luasnya sama dengan luas perkebunan yang sudah dan akan dibangun yaitu seluas 6,7 juta ha. Keadaan demikian telah memberikan 'keuntungan tambahan' bagi perusahaan perkebunan yang berupa kayu dari pembukaan lahan. Kesempatan yang demikian ini sering dimanfaatkan oleh perusahaan perkebunan untuk melakukan mark up atas luas kebun yang diperlukan. Dalam kenyataanya di beberapa propinsi ditemukan perusahaan perkebunan yang hanya mencari lokasi, melakukan pembukaan lahan untuk mendapatkan kayu, dan kemudian meninggalkannya tanpa melakukan pembangunan perkebunan.

4. Tidak adanya institusi penatagunaan hutan yang baik, yang disebabkan lemahnya kebijakan penggunaan lahan nasional dan aspek-aspek politik ekonomi, telah menyebabkan pelaksanaan pembangunan HTI dan perkebunan telah secara nyata menimbulkan masalah sosial yang berkaitan dengan penggunaan lahan. Salah satu aspek politik ekonomi yang mendorong degradasi hutan alam adalah adanya kenyataan diversifikasi usaha HPH berupa usaha HTI dan perkebunan, sehingga ketika HPH menyisakan hutan yang rusak, maka HTI dan/atau perkebunan mendapat legalitas untuk menempati lokasi hutan yang rusak.

5. Faktor utama yang mendorong perkembangan pembangunan HTI adalah adanya subsidi dan kemudahan untuk mendapatkan lahan hutan sebagai lokasi HTI. Kemudahan ini telah menyebabkan sebagian besar pembangunan HTI dilakukan pengusaha swasta untuk mendapatkan kayu dari konversi hutan alam dan untuk mendapatkan dana murah yang disediakan pemerintah. Hal ini ditunjukkan oleh rendahnya realisasi pembangunan HTI yaitu hanya mencapai $23,1 \%$. Di pihak lain terdapat suatu ironi bahwa dengan harga kayu dari hasil HTI yang relatif murah dan ketidakpastian adanya investasi pabrik yang dapat memanfaatkan kayu hasil HTI sebagai bahan bakunya, justru mendorong pengusaha swasta terus-menerus minta ijin pemerintah untuk membangun HTI.

6. Ada beberapa pengusaha swasta yang membangun HTI tanpa subsidi dari dana reboisasi. Kelompok pengusaha yang memilih pembangunan HTI tanpa subsidi menganggap manfaat subsidi, yang berupa dana reboisasi tanpa bunga, lebih kecil daripada biaya transaksi yang ditimbulkannya. Biaya transaksi ini muncul karena masuknya Badan Usaha Milik Negara ke dalam tubuh perusahaan dalam bentuk usaha patungan serta biaya-biaya yang timbul dari pengurusan pencairan dana reboisasi. Kenyataan di atas menunjukkan bahwa usaha HTI tanpa subsidi juga menjadi pilihan pengusaha, artinya HTI tanpa subsidi masih menguntungkan.

7. Penggabungan Direktorat Jenderal Perkebunan ke dalam struktur organisasi Dephutbun belum menghasilkan kebijakan yang diperkirakan mampu 
memberikan penyelesaian masalah tumpang tindih penggunaan kawasan hutan. Permasalahan dalam pelaksanaan padu serasi antara TGHK dan RTRWP belum terpecahkan walaupun sektor perkebunan dan kehutanan sudah digabungkan.

8. Sampai saat ini belum terdapat kebijakan dan implementasi di lapangan yang mampu memecahkan masalah tata guna lahan dan hutan. Memperhatikan apa yang diperbuat oleh pengusaha swasta dalam mempengaruhi keputusan-keputusan alokasi lahan dan hutan terdapat indikasi bahwa ketidakpastian tata guna lahan dan hutan telah menguntungkan pengusaha swasta yang mempunyai akses untuk mempengaruhi pelaksanaan alokasi lahan dan hutan. Sementara itu, di pihak lain, pengambil keputusan dengan perilaku rent seekingnya memperoleh keuntungan dari situasi tersebut.

\section{Rekomendasi}

Untuk menyelamatkan hutan alam yang masih tersisa, pemerintah perlu melakukan perubahan status hutan negara, sehingga hutan alam primer yang saat ini berada di dalam kawasan hutan produksi yang dapat dikonversi diubah menjadi hutan tetap yang tidak dapat dikonversi untuk keperluan lain. Sementara itu, pembangunan HTI dan perkebunan besar diarahkan pada hutan produksi yang tidak produktif.

Dalam implementasinya diperlukan proses pengukuhan kawasan hutan dengan memperhatikan keberadaan hutan adat dan kondisi sosial ekonomi masyarakat yang tinggal di dalam dan sekitar hutan. Pelaksanaan ini benar-benar dapat dilakukan jika ditunjang oleh perubahan orientasi organisasi Dephutbun baik di pusat maupun di daerah, sehingga mampu memfasilitasi pelaksanaan alokasi hutan dan lahan di lapangan. Sejalan dengan hal ini diperlukan desentralisasi untuk meningkatkan peran pemerintah daerah dan instansi kehutanan dan perkebunan di daerah dalam pelaksanaan redistribusi pengelolaan hutan dan lahan yang saat ini sedang dijalankan. Dalam implementasinya karakteristik biofisik dan kondisi sosial ekonomi di daerah masing-masing diharapkan dapat dipertimbangkan.

\section{Ucapan Terimakasih}

Kedua penulis menyampaikan ucapan terimakasih kepada William D. Sunderlin yang telah memberi kesempatan sehingga studi ini dapat dilakukan serta pemikiran dan komentarnya atas tulisan ini. Di samping itu juga kepada Anne Casson, Dudung Darusman dan Rita Lindayati atas waktu yang disediakan untuk mengomentari tulisan ini. Penulis bertanggung jawab atas kesalahan substansi yang mungkin masih dijumpai dalam hasil akhir tulisan ini.

\section{Catatan Akhir}

1 TGHK (Tata Guna Hutan Kesepakatan) adalah pembagian hutan negara menurut fungsinya yaitu hutan lindung, hutan konservasi, hutan produksi, serta hutan produksi yang dapat dikonversi. TGHK ditetapkan sejak tahun 1983 oleh Departemen Kehutanan yang disepakati oleh Pemerintah Daerah serta sektor lainnya. RTRWP (Rencana Tata Ruang Wilayah Propinsi) adalah pembagian tata ruang wilayah propinsi sebagai penjabaran dari Undang Undang Tata Ruang Tahun 1992. Dalam RTRWP dikenal pembagian ruang sebagai hutan lindung, kawasan budidaya kehutanan dan kawasan budidaya nonkehutanan. Dalam implementasinya, sejak tahun 1993, antara TGHK dan RTRWP dipaduserasikan.

2 Lahan kritis yang dimaksud biasanya juga meliputi lahan yang seharusnya berfungsi konservasi atau perlindungan.

3 "50 PMA Sedang Bangun Perkebunan Kelapa Sawit". Neraca. 14 Juli 1998.

4 "Menhutbun Tetapkan Kriteria Baru Pembukaan Kebun Sawit”. Neraca. 11 April 1998.

5 "BUMN Perkebunan Sudah Diincar Asing". Kompas. 2 September 1998.

6 Perum Perhutani dan PT INHUTANI adalah Badan Usaha Milik Negara yang bekerja dalam bidang pengelolaan hutan.

7 “PT INHUTANI III Mulai Garap Sawit”. Suara Karya. 18 Juni 1998.

8 "PT INHUTANI I akan Memasuki Bisnis Perkebunan". Suara Pembaruan, 23 Juni 1997.

9 "BUMN Kehutanan Diizinkan Masuk Usaha Perkebunan”. Neraca, 05 Mei 1998.

${ }^{10}$ Hasil diskusi "Pemberdayaan Ekonomi Masyarakat Berbasis Sumber Daya Alam: Studi Kasus Perkebunan dan Kehutanan", 9 Maret 1999, yang diselenggarakan oleh Kelompok Kajian Pengelolaan Sumber Daya Berkelanjutan (K3SB), di Bogor.

${ }^{11}$ Kawasan hutan negara menjelaskan statusnya secara hukum bahwa hutan tersebut hutan milik negara. Kawasan hutan negara tidak selalu berhutan, sehingga peningkatan kawasan hutan dapat berarti secara hukum kawasan hutan negara naik jumlahnya, tetapi luas yang berhutan dapat menurun. Pada tahun 1984, kawasan hutan negara ditetapkan berdasarkan TGHK. Sedangkan pada tahun 1997 kawasan hutan negara berubah setelah dilakukan paduserasi antara TGHK dengan RTRWP.

12 Berdasarkan luas pencadangan areal kerja HTI sebanyak 44 unit yang telah mendapat SK HP-HTI. Seluruh HTI yang sudah disahkan RKTnya sebanyak 132 unit, terdiri dari HTI Pulp 22 unit, HTI Kayu Perkakas 47 Unit dan HTI Transmigrasi 63 Unit. Sasaran tahunan pembangunan HTI seluas 250.000 ha. Dephutbun (1998). 
${ }^{13}$ Saat ini Peraturan Pemerintah ini sudah diubah menjadi Peraturan Pemerintah No 6 tahun 1999. Meskipun demikian ketentuan tersebut tidak berubah.

${ }^{14}$ Pengalaman penulis dalam melaksanakan studi kelayakan pembangunan HTI di Kalimantan dan Sumatera sebanyak 6 unit, pada tahun 1990-1995.

15 Data yang digunakan bersumber dari Departemen Kehutanan dan Perkebunan. Bahan Rapat Ekuin 3 Agustus 1998.

16 "BUMN Kehutanan Diizinkan Masuk Usaha Perkebunan". Neraca, 5 Mei 1998.

17 "Luas Hutan yang Dikonversi untuk Perkebunan 7 Juta ha”. Suara Pembaruan, 10 Oktober 1997.

18 "Minat Investor Perkebunan Masih Tinggi". Suara Pembaruan, 26 Juli 1998.

19 "Selamatkan Taman Nasional Bukit Tigapuluh". Suara Pembaruan, 14 September 1998.

${ }^{20}$ Informasi diperoleh dari Departemen Kehutanan dan Pusat Data Bisnis Indonesia, berbagai tahun.

21 "Sampai Juli 1997 Realisasi Penanaman HTI Pulp Baru 23,1\%”. Neraca, 7 November 1997.

22 "10 Perusahaan Perkebunan Di Bengkulu Akan Dicabut Izinnya”. Suara Pembaruan, 22 Agustus 1998. On line.

23 "Izin Prinsip Perkebunan di Riau yang Ditelantarkan Akan Segera Dicabut". Suara Pembaruan, 27 Juli 1998. On line.

24 "Pemda Kaltim Akan Mencabut 50 Izin Lokasi Perkebunan”. Suara Pembaruan, 14 Agustus 1998. On line.

25 "41.155 ha Perkebunan Rakyat Sumsel dicaplok 13 Perusahaan". Bisnis Indonesia, 3 September 1998.

${ }^{26}$ Siaran Pers Bersama Lembaga Bantuan Hukum Palembang dan Konsorsium Pembaruan Agraria Sumsel. Dalam Peringatan Hari Tani. 24 September 1998.

27 "Pembabatan HTI di Lampung Meluas". Kompas, 28 September 1998.

28 "Lahan PTPN II Dijarah Massa”. Kompas, 14 Juli 1998.

29 "Menhutbun: Saya Akan Cek Oknum yang Mencuri Kelapa Sawit”. Sinar Pagi, 18 April 1998.
30 "Harga Jual Produk Plasma Ditentukan Pasar". Sinar Tani, 14 Oktober 1998.

31 "Pengusaha Perkebunan Kembali Naikkan Upah". Sinar Tani, 14 Oktober 1998.

32 "Petani Kopi antara Jutawan dan Ancaman Perampokan". Sinar Tani, 26 Agustus 1998.

${ }^{33}$ Berdasarkan PP No. 7 Tahun 1990, salah satu tujuan pembangunan HTI adalah meningkatkan produktivitas lahan dan kualitas lingkungan hidup.

${ }^{34}$ Pengalamaan PT Kiani Hutani Lestari dan PT ITCI Hutani Manunggal dua perusahaan HTI di Kalimantan Timur pada tahun 1995-1996 ketika akan memanen hasil HTInya mengalami kesulitan untuk menjualnya, sehingga pemanenannya ditunda.

${ }^{35}$ Pengalaman penulis pada saat mengikuti pembahasan beberapa studi kelayakan pembangunan HTI di Departemen Kehutanan dan Perkebunan antara tahun 1990-1994.

${ }^{36}$ Pernyataan ini adalah kesan penulis selama mengikuti berbagai diskusi dan pertemuan-pertemuan lainnya tentang pembangunan HTI yang melibatkan atau diprakarsai oleh pemerintah.

${ }^{37}$ Biaya transaksi (transaction cost) dapat berupa biaya untuk mengukur nilai atribut barang dan jasa (information cost) yang akan dipertukarkan, biaya untuk melindungi hak atas barang (exclusion cost), biaya untuk menetapkan kontrak/perjanjian (contractual cost), serta biaya untuk menjalankan perjanjian (policing cost).

${ }^{38}$ Salah satu hasil lokakarya sosialisasi ekolabel yang dilakukan oleh Lembaga Ekolabel Indonesia dan GTZ di Samarinda, Kalimantan Timur. 3-4 Nopember 1998. Lokakarya ini dihadiri oleh lebih 200 peserta dari HPH, HTI, Pemerintah Daerah, Perguruan Tinggi, LSM, dan Instansi Kehutanan di daerah.

${ }^{39}$ Hasil diskusi dengan Ir. Diah Rahardjo, staf pada GTZ Samarinda, Kalimantan Timur.

${ }^{40}$ Uraian detail mengenai hal ini dapat dilihat dalam Sunderlin (1998). 


\section{Daftar Pustaka}

Arifin, S. and W.R.Susila.1998. Indonesia as a Major Palm Oil Producer: Prospects and Challenges. Center for Economic Studies. Research and Development. Departmen of Agriculture. Bogor.

Casson, Anne. 1999. The Hesitant Boom: Indonesia's Oil Palm Sub-Sector in an Era of Economic Crisis and Political Change. Programme on the Underlying Causes of Deforestation. Bogor, Indonesia: Center for International Forestry Research.

Dephut. 1996. Statistik Sumber Daya Hutan Indonesia II (Kecuali P. Jawa). Proyek Inventarisasi Hutan Nasional. Ditjen Intag. Departemen Kehutanan dengan bantuan teknis FAO. Jakarta.

Dephut. 1997. Laporan Akuntabilitas Menteri Kehutanan Periode 1996/1997. Jakarta.

Dephutbun. 1998a. Penataan Ulang Penguasaan Lahan dan Pengusahaan Hutan Skala Besar dalam Rangka Redistribusi Manfaat Sumber Daya. Jakarta.
Dephutbun. 1998b. Arah, Strategi dan Kebijaksanaan Pembangunan Kehutanan dan Perkebunan Kabinet Reformasi Pembangunan dan Tanggapan Pemerintah atas Laporan Kunjungan Kerja Komisi III DPR-RI Dalam Reses Masa Persidangan III. Tahun Sidang 1997/1998. Jakarta.

Ditjenbun. 1998. Laporan Pelaksanaan dan Penilaian Perkebunan Inti Rakyat. Jakarta.

Sunderlin, William D. 1998. Between Danger and Opportunity: Indonesia's Forests in an Era of Economic Crisis and Political Change. September 23, 1998. http://www.cgiar.org/cifor/

Susila, W.R. 1998. Perkembangan dan Prospek Komoditas Utama Perkebunan. Pusat Studi Ekonomi. Lembaga Penelitian dan Pengembangan Pertanian. Bogor.

Susila, W.R. 1997. Model Ekonomi Minyak Sawit Mentah Dunia. Pusat Studi Ekonomi. Lembaga Penelitian dan Pengembangan Pertanian. Bogor. 